\title{
A Study on the New Design Thinking for Industrial Revolution 4.o, Requirements and Graduate Readiness
}

\author{
Swayamprabha Satpathy', Kabita Kumari Dash² \& Malvika Mohapatra \\ ${ }^{1}$ Associate Professor, Shiksha "O" Anusandhan University, Bhubaneswar. Email: \\ dr.swayam.prava@gmail.com \\ ${ }^{2}$ Assistant Professor, Srusti Academy of Management, Bhubaneswar \\ ${ }^{3}$ Assistant Professor, Shiksha "O" Anusandhan University, Bhubaneswar
}

\begin{abstract}
The Fourth Industrial Revolution can be regarded as Industry 4.0 connected with the developments, innovative approaches and technological advancements held in the year 2011 at Germany. It is the amalgamation of many digital technologies such artificial intelligence (AI), robotics, Internet of Things (IoT) cloud computing, big data, $3 \mathrm{D}$ printing etc. The present study is qualitative in nature and focuses on graduate readiness, the challenges faced by the engineering students of SOA university, Bhubaneswar to meet the industry 4.0 requirements because technical degree is not only the gateway to their success in industry rather they should equip themselves with various soft skills like English language development, communication, personality development, leadership, critical thinking, problem solving and team building skills to meet the expectations of their employers. The objective of this study is to analyze the current education practices and the industry requirements and come out with best possible solutions for industry readiness of graduate engineers for a successful corporate career. The study has put some valuable insights on the problems faced by the $5^{\text {th }}$ semester students related to language acquisition and their readiness for future industrial demands. Furthermore, universities should also come out with appropriate suggestions and recommendations to enable graduate engineers for future industry readiness.
\end{abstract}

Keywords: English language, Communication, Industrial revolution 4.o, Graduates' readiness, Employers Demand, Digital technology, Technical graduates

\section{Introduction}

Industrial Revolution 4.0, built on the technological inventions of the third IR, is replacing and even removing jobs at a higher speed. The World Economic Forum's (WEF) Future of Jobs report states that 65 percent of children entering primary schools today will end up working in such jobs that do not exist yet. The report also observes that most of the language use that is currently in demand did not exist few years ago. The current employment market changes from the recent years as expected to lead to significant loss of jobs. The quality of graduates that enter the workforce is not good enough to meet the ever-changing demands of the competitive market.In the present Industrial Revolution 4.0 when the demand is on features like Artificial Intelligence, Cloud Computing, Supply Chain Management, are the graduates ready to efficiently work with these paradigm shifts? However, industrial revolution 4.0 can fundamentally change the way we work, live and connect to each other (Schwab, 2016).

Education 4.0 is an occurrence that happens as a response to the needs of the industrial revolution 4.0, where human and machines work together for better project output and finding solutions of various problems through a number of innovations meant for the development of

(C) AesthetixMS 2020. This Open Access article is published under a Creative Commons Attribution Non-Commercial 4.o International License (http://creativecommons.org/licenses/by-nc/4.o/), which permits non-commercial re-use, distribution, and reproduction in any medium, provided the original work is properly cited. For citation use the DOI. For commercial re-use, please contact editor@rupkatha.com. 
human society. Dunwill (2016) states that future classrooms will be virtual learning platforms focusing mainly on soft skills like problem solving, critical thinking ability, leadership, effective communication and innovative approaches in learning. Furthermore, learning contents will more focus on digital literacy, building life skills, leadership, accountability, productivity and responsibility (Trilling \& Fadel, 2009).

Design thinking is a unique, creative and innovative technique which redefines communication pattern through value added soft skills and help the graduates in better role clarity and performance in the organization. In addition, the novel pedagogy of teaching and learning, the English language is campus driven where the graduates can showcase their potential, talent and personality during the selection process which is an essential prerequisite to get into the corporate world. (Ranger \& Mantzavinou, 2018).

India is among the few economies in the ASEAN countries where unemployment rate is very is high. It produces a number of technical graduates throughout India. As per the data from Department of Statistics (DOSM) and the Ministry of Higher Education (MoHE) the unemployment is more severe for technical degree holders. Graduate readiness in response to industrial revolution 4.0 challenges the current university education system. However, according to MoHE, emerging technological advancements, focusing on digital resilience and human connectivity, institutional accountability and governance are the key strategies for growth and survival. Still there is a long way in adaptability of this mechanism in the university engineering curriculum.

Majority of studies related to industry 4.0 requirements highlight the problem of lacking proper skill-set and this is the main reason behind their rejection during the hiring process. Employers show their reluctance to absorb these types of candidates by considering them as inefficient (Ahmadl- \& Suhaili, 2015). Industry leaders now acknowledge that our universities are not able to produce work-ready graduates without the academia acquiring a clear, accurate and updated understanding of what companies look for at the entry-level employers. According to the study by Talent Corp survey, it is found that 53 percent of firms have never engaged career centers in their recruitment efforts. This goes to suggest that even though companies may comment that graduate lack requisite skills, efforts can still be made to prepare these graduates for workforce entry, perhaps through concerted partnerships between industry and academia.

\section{Objectives \& Methodologies}

The objectives of this study are:

- To analyze the current education practices and the industry requirements

- $\quad$ To come out with best possible solutions for industry readiness of graduate engineers for a successful corporate career.

The present study has highlighted the following issues by putting some valuable insights and finding appropriate strategies to address:

- Factors affecting the students' readiness for future industrial demands

- Industrial demands of English communication for technical graduates

- Whether there is a need to change the thought process of the mentors and student 
The research methodologies adopted for this study is complete library research mainly based on secondary data collection techniques. The other methodologies adopted in this study are personal meetings, interviews and discussions with fifth semester engineering students of SOA University who already completed their Summer Internship Programme (SIP) and were taking up industrial trainings so as to be fit in this global competitive corporate environment. Total 531 students are taken as samples for this study with detail discussion and analysis of the problems they face during communication and presentation in the classroom. Information were also collected from secondary sources to know their participation and attendance during language and communication classes. Personal one to one interaction with the respondents was very helpful in finding the gap between the curriculum followed in academic institutions and industry requirements related to business communication.

\section{Literature Review}

The present study contains extensive literature review related to importance of communicative competence through design thinking among graduates for a gainful employment after studies and various factors that affect the readiness of engineering graduates in bridging the gap between Industrial Revolution 4.0 requirements.

Dunne \& Martin (2006) elaborates on design thinking process which has started to receive increased attention in organizational settings. This is because the design of products and services is a major component of industry competitiveness, to the extent that many known companies have committed themselves to become design leaders. And although design thinking has become an integral part of the design and engineering fields as well as used in industries, it can also have a positive influence on 21st century education across disciplines because it involves creative thinking in generating solutions for problems. That is, in academic environments, students are required to read critically, think and reason logically, and solve complex problems as cited by Rotherham \& Willingham (2009). Thus, to help students succeed in this interconnected, digitalized world we live in, educators should support students in developing and honing $21^{\text {st }}$ century skills (e.g., design thinking, systems thinking, and teamwork skills) that enhance their problem-solving skills and prepare them for college and career according to Shute \& Torres(2012).

In business settings, innovative design thinking is the need of the hour in the fields like engineering, architecture because it can change how people learn and solve problems (Dym,C.L et.al.,2005). Success will be a distant dream if graduates lack employability skills like job seeking skills, interview skills, presentation skills which require a certain level of competency in English.

Rifkin (2014) advocates for taking up innovative approaches in communication through technological advancements for a holistic growth and development. Moreover, the impact of Information and Communication Technology (ICT) has taken one step ahead in the new design thinking process and the strategies that should be taken up keeping in view of the industrial requirements. A useful base to start with is using the theme graduate readiness in its entirety, which puts emphasis on the requirements of present generations without compromising the ability of future generations.

Simon (1996) opines design thinking to be the central or distinguishing activity of engineering. It has also been said that engineering programs should promote graduate engineers who can design effective solutions to meet social needs (Evans et.al, 1990). Being successful in today's highly technological and globally competitive world requires a person to develop and use 
a different set of skills than were needed before (Shute \& Becker, 2010). Like problem solving, design thinking is a natural and ubiquitous human activity. Braha \& Maimon (1997) states that a design process starts with the dissatisfaction with the current state combined with a determination that some action must be taken to solve the problem. Many scientists have been designing and acting as designers, throughout their careers, often not recognizing or being aware that they are performing in a design process.

According to Alvin Toffler and Future Shock (1970), "The illiterate of the 21st century will not be those who cannot write and read, but those who cannot learn, unlearn, and relearn". Academicians have a huge responsibility of transforming the society through imparting advanced learning to its graduate engineers. They must build the skills of these graduates so as to help them in making the right career decisions and prosper at work. To be the agents, of change and part of this social transformation process, our graduate engineers need to be adaptive, well prepared and well informed. They must be aware of this technology driven learning for grooming their soft skill etiquettes. Further they need to understand industry requirements and their potential disruption to future job markets, selection and recruitment.

Teng et al., (2019) suggest that industrial revolution 4.0 requires technical knowhow combined with soft skills and social adaptability focusing more on communication, personality development, leadership, team work, innovativeness, problem solving and critical thinking ability. In addition, university curriculum should be designed in such a way so as to enhance students' preparedness for employment after understanding the problem of underemployment among graduates by changing the employers' perception that graduates lack the basic soft skills for their organization or workplace.

Doepker (2019) predicts in the report of the World Economic Forum "The Future of Jobs" that 75 million jobs will be displaced by automation by 2022 worldwide. But during this period there will be another 133 million new jobs added to the global economy. However, due to lack of skilled human resources and absence of requisite qualification many of these posts will remain vacant. This may be rightly called the skills gap which has been a problem for a decade and this problem is not also going to be resolved till the universities and department of higher education find possible measures. But in most cases, the workers who lose their current jobs will not have the necessary qualifications to fill the new positions, ones that are already emerging and going largely unfilled. The aptly named "skills gap" has been a problem for the last half-decade, and the problem will not resolve until our institutes of higher education find ways to acclimatize to the emerging demands of the global economy.

The World Bank-Talent Corp Survey on Graduate Employability found that 80 percent companies are of the view that university graduates should have more industrial training by the time they graduate, and more than 81 percent corporate houses emphasized on language and communication skill to be a major requirement among graduates. It is widely seen that English language and communication is the best medium to interact with others inside or outside the industry in this era. The issue is highlighted to ensure that the graduates are equipped with hard skills for their particular field of work, as well as their communication skills to visualize the effective interaction which should occur among the workers. While India has progressed in the various fields towards becoming a developing nation, there is a strong competitiveness among the students to meet the growing corporate demand. In this backdrop, achieving our national economic development goals solely depend upon the ability of our workforce to adapt and cope with the increasing demand for skilled capabilities and quality results. Business leaders also now understand Industry 4.0 will bring dramatic changes and they need to prepare the technocrats. 
Yet, they are less certain so as to implement, and with the innumerable changes its difficult within the stipulated time. In this age of unprecedented global social and economic connectivity, if leaders choose to think more intricately and act decisively, organizations may play a leading role in ensuring Industry4.0 and can act as a positive force.

As per the findings of Ezihaslinda Ngah et al (2011), recruiters always emphasize on excellent work efficiency with a sound technical background of the candidates during the hiring process The global economic environment has led to business focusing on Red Ocean strategies, aiming to shift from the battle for market share within known market spaces, to Blue Ocean strategies with moves to create new products or services and new demand in uncontested market space. This new perspective has further developed to a White Ocean strategy, which emphasizes social concerns focusing on People, Planet, Profit, and Passion (Chanchaochai, 2012). The ongoing changes in business attitudes and strategies have heavily influenced the way in which workplace English is used for communication.

Thus a mastery over English Language is an essential pre-requisite for professional career which enhances productivity in the work place by meeting organization objectives. According to Hiranburana K. (2017), with increased expansion of communication technologies and electronic media, it is worth exploring the change in the thought process of learners to adapt a language which is not a language of their comfort area. Furthermore, using traditional methods such as interviews to measure attitudes, these studies have come to conclusions as to learners' needs which have implications for the design of English for specific purposes courses (Bhatia \& Bremner, 2012). Other researchers like Wiriyachitra (2001) who has looked into English requirements in the workplace have emphasized the importance of competence in listening and speaking suggesting that the English curriculum in universities in its current form cannot meet the demands for English as used in the workplace.

This study shows that global business people have greater use of written English than spoken English for communication and that the main medium is email which, unlike other forms of written English, shares several features with the spoken language (Hiranburana, 2017).

Chang (2004) elaborates that proficiency in English means the ability to present ideas, explain issues and problems, to speak up in a constructive manner, to resolve problems, to understand issues and problems faced by companies and to come up with workable solutions to problems are all good communication and interpersonal skills sought after by employers. Therefore, employees are expected to contribute from 'day one of being hired'.

Ayiesah Ramli et al. (2010) adds to the notion that communication skills comprises of making effective presentations, having the ability to put up a good logical argument to persuade others, as well as the ability to express idea verbally - one to one or two groups, having relevant skills in written communication such as emails, reports, letters to clients, the ability to listen attentively and respond to others' comments ideally. On top of that, communication skills are the ability of an individual which consistently strives to effectively communicate with clients, colleagues, subordinates, and supervisors in professional manner and in the personal department. Communication skill is generally the use of oral language and written language used for the art or technique of persuasion. In order to enhance learning of English for communication in business, course material designers should include common language patterns used in e-mails. Students should be encouraged to engage in collaborative and co-operative writing processes including problem solution and in the negotiation of meaning on a variety of topics, not only related to 
business. Students should also discuss issues to improve quality of life such as green projects and sports activities.

Now a day's globalization is forcing companies to redesign, rethink and innovate new strategies so as to keep pace with the industry 4.0 requirements. The implementation of this model will bring a huge change with big investments so the new graduates need to know this 4.0 work ecosystem, use their soft skills for a productive output (Petrillo et.al, 2018). The emerging fourth industrial revolution has paved path for rapid changes and technological advances and organizations need to keep pace with such changes in order to have a sustaining growth. Proper and effective management of human resources, trainings, orientation and open lines of communication are highly necessary to keep up this competitive spirit in the organization (Stacho, Z. et. al, 2019)

Passow, J. H. \& Passow, C.H. (2017) find engineers are having a vital skill of using their manifold competencies to achieve their goals .Moreover, engineers should be educated and trained to assimilate knowledge across a range of industries with their multi talents, diversified knowledge, social and soft skill competencies. They all must have interdisciplinary approach, sound system knowledge, creative competency, ideas on sustainable entrepreneurship, and having the ability of problem solving and decision making skills to solve intricate problems related to big data. It is equally important that engineers need to enhance their project management skills for a good network, collaboration, increased work efficiency beyond the technology requirements.

As per the recommendations of World Economic Forum, to prepare for the fourth industrial revolution countries need to groom their future workforce through a redesigned improved curriculum with innovative training approaches (WEF \& Kearney, 2018).

\section{Analysis and Discussion}

During the study it is found that students are not very adaptable to acquiring communication and soft skills as against technical skills, which negatively impact their future academics and profession. As most of them were from rural setting and comfortable in communicating in their native language, it became imperative for the teachers to critically analyze and understand the need of effective communication and finding appropriate strategies so as to prepare them for dynamic corporate world. So, higher education need to explore and innovate strategies to fulfill the demands of this fast changing world by keeping pace according to WEF report 2019.

In the present scenario, rising economies are faced with shortages of talent and funding. So there should be greater cooperation and partnership with other universities in India and abroad for establishing a sound educational ecosystem for exchange of knowledge, ideas and innovations. But for this, collaboration between government, industry and academia is crucial for supporting universities in preparation and effective implementation of 4 IR strategies to enhance graduate readiness.

In our survey with 531 youth and engineering students as respondents of SOA University, the following findings came out.

Table 1 showing the average percentage of student responses on different factors

\begin{tabular}{|l|l|l|l|l|}
\hline Factors affecting 4.0 requirements & Boy & Girl & NA & Total \\
\hline
\end{tabular}


7 A Study on the New Design Thinking for Industrial Revolution 4.0, Requirements and Graduate Readiness

\begin{tabular}{|c|c|c|c|c|}
\hline Gender & $46 \%$ & $52 \%$ & $2 \%$ & $100 \%$ \\
\hline Location & City & Town & Rural & \\
\hline $\begin{array}{l}\text { A vast majority of engineering students live in } \\
\text { cities }\end{array}$ & $69 \%$ & $24 \%$ & $7 \%$ & $100 \%$ \\
\hline Age & $15-19$ & $20-24$ & $25-29$ & \\
\hline $\begin{array}{l}\text { Number of students enrolled in technical } \\
\text { institutions and other formal education } \\
\text { according to their age }\end{array}$ & $62 \%$ & $38 \%$ & -- & $100 \%$ \\
\hline $\begin{array}{l}\text { Enrollment in } \\
\text { institutions/universities }\end{array}$ & Full time & Part Time & NA & \\
\hline Students enrolled in technical colleges & $40 \%$ & $17 \%$ & $43 \%$ & $100 \%$ \\
\hline Industry Preferences for work & Yes & No & NA & \\
\hline $\begin{array}{l}\text { Students look for work after technical } \\
\text { education }\end{array}$ & $79 \%$ & $21 \%$ & -- & $100 \%$ \\
\hline Jobs & Yes & No & NA & \\
\hline $\begin{array}{l}\text { Students engaged after formal technical } \\
\text { education }\end{array}$ & $32 \%$ & $50 \%$ & $18 \%$ & $100 \%$ \\
\hline Types of Jobs & Private & Public & NGO & Family Business \\
\hline Students engaged in different sectors & $37 \%$ & $30 \%$ & $19 \%$ & $14 \%$ \\
\hline Country Preferences & India & USA & UK & $\begin{array}{l}\text { Nepal \& other } \\
\text { Asian countries }\end{array}$ \\
\hline $\begin{array}{l}\text { Students enrolled in technical colleges } \\
\text { worldwide }\end{array}$ & $10 \%$ & $40 \%$ & $30 \%$ & $20 \%$ \\
\hline
\end{tabular}

Source: Global Youth Survey 2018, Preparing tomorrow's workforce for the Fourth Industrial Revolution | For business: A framework for action

Table- 1 depicts most of the student respondents are girls (52\%) and boys (46\%). It is seen that the majority of girls interest for engineering education might be due to the fact of changing job roles in present scenario. Many Indian parents are also of the view of finding the prospective groom for their daughters if their daughters will have some technical degree. The vast majority of student respondents live in cities (69\%), towns (24\%) and rural areas (7\%). Out of them only $40 \%$ students enrol themselves for technical engineering education in full time mode. Total $79 \%$ students look for industry jobs after graduation degree and $21 \%$ think to go for other jobs. However, out of total students only $32 \%$ get jobs because of their communication skill, technical knowledge, good outlook and understanding on the business requirements. It is found from the study that $37 \%$ students get engaged in industries, $30 \%$ in public sector, $19 \%$ in Non Government 
Organisations and $14 \%$ students go for their family businesses. It is also revealed from the study that majority of students (40\%) prefer to work in USA and UK (30\%) because of lucrative salary, perks and benefits unlike other Asian countries.

Table 2 showing the average percentage of student responses on Industry 4.o

\begin{tabular}{|c|c|c|c|c|}
\hline $\begin{array}{l}\text { Knowledge and awareness about } \\
\text { Industry } 4.0 \text { and future of work }\end{array}$ & Yes & No & Not sure & \\
\hline $\begin{array}{l}\text { Students Knowledge and awareness } \\
\text { about Industry } 4.0\end{array}$ & $54 \%$ & $26 \%$ & $20 \%$ & $100 \%$ \\
\hline $\begin{array}{l}\text { Universities not preparing with the } \\
\text { skill set required for job }\end{array}$ & Agree & Strongly Agree & Disagree & $\begin{array}{l}\text { Strongly } \\
\text { Disagree }\end{array}$ \\
\hline $\begin{array}{l}\text { University do not prepare the } \\
\text { students with the skills required for } \\
\text { the job }\end{array}$ & $45 \%$ & $16 \%$ & $26 \%$ & $13 \%$ \\
\hline $\begin{array}{l}\text { Requirement of soft skill training } \\
\text { outside the education for industry } \\
\text { readiness }\end{array}$ & Yes & No & NA & \\
\hline $\begin{array}{l}\text { Students have to go outside for } \\
\text { trainings }\end{array}$ & $79 \%$ & $21 \%$ & & \\
\hline $\begin{array}{l}\text { Student Interest for adopting } \\
\text { different types of innovative } \\
\text { pedagogy for learning and meeting } \\
\text { 4.o requirements }\end{array}$ & $\begin{array}{l}\text { Self guided } \\
\text { learning/ } \\
\text { certificate courses }\end{array}$ & $\begin{array}{l}\text { Online } \\
\text { learning }\end{array}$ & $\begin{array}{l}\text { Employment } \\
\text { related job } \\
\text { training }\end{array}$ & \\
\hline $\begin{array}{l}\text { Students faith on different types of } \\
\text { skill trainings which will make } \\
\text { them industry ready }\end{array}$ & $58 \%$ & $24 \%$ & $18 \%$ & \\
\hline
\end{tabular}

Source: Global Youth Survey 2018, Preparing tomorrow's workforce for the Fourth Industrial Revolution | For business: A framework for action

Table- 2 analysis finds that 54\% students are having knowledge and awareness about industry 4.0 requirements and they prepare themselves accordingly. $45 \%$ students believe that their university and institutions do not prepare them with the skills required for the job. So, total $79 \%$ students go for outside trainings for their soft skill enhancement. 58\% student show their interest to do some certificate course or specialization course like AutoCAD, ERP-SAP, Multi Media for meeting the corporate requirements.

Industrial Revolution 4.0 has also brought a number of changes in human lives. The education sector should bring various reforms so that students after completion of their graduation can cope with this change as well as compete and contribute meaningfully. The present and future academic curriculum should be redesigned in such a way so that the graduates can have better soft skills and life skills. In addition policy makers and academicians should also take proactive role in shaping the career of these graduates so that they all can be skilled and potential human 
beings by using computerization, big data, Internet of Things (IoT) and ICT based learning platforms (Lase, 2019).

\section{Suggestions}

- Engineering curriculum should be redesigned keeping in view of the industry 4.0 requirements.

- The engineering graduates should be adequately trained on this curriculum combined with advanced teaching and learning pedagogy with frequent practical industrial exposure.

- As normal curriculum consists of development of training modules, appropriate training needs assessment strategies, learning outcomes, more research needs to be conducted across universities of the country and abroad to build a comparative framework appropriate for graduate engineers readiness so as to meet the global standards.

- The curriculum outcome should meet the 4IR competency of engineers in both specialized and general category.

- A concerted and coordinated effort of AICTE, MoHE and academia is essential for Implementation of this new designed curriculum meant for graduate engineers at national and university level.

- Discussions, debates, panel discussions, workshops, seminars at both national and international levels need to be organized for developing a framework and its effective implementation for 4.0 industry requirements

- Digital literacy, technical trainings and soft skills orientation are to be mandatory for all the university graduates so as to meet the 4.o standards

- There should be more student exchange programmes for proper project management, sustainable entrepreneurship promotion, and development of personal and social skills.

\section{Conclusion}

English Language teaching should be designed in such a way which can enhance the employability skills of graduate engineers making them better communicators as well as contributors towards societal development. The academic curriculum should be redesigned keeping in view of this global competitive work environment.

The present study demonstrates and analyses the basic requirements of graduate engineers in all the technical universities to meet the fourth industrial requirements. The recent policies and programmes of higher and technical education need to be improvised and priorities should be given to soft skill requirements of graduates. Effective interpersonal communication and written communication not only helps in personal growth but also overall development of organizations through increased competitiveness and a good network.

This qualitative library study has been prepared after analyzing the problems of engineering graduates passing out from SOA university in getting an appropriate corporate exposure. But it can be extended to other universities to have more in-depth understanding of the problems of graduate engineers related to soft skills, which is a major hindrance in the path of their employment. Other researchers can also take up empirical studies for assessment of this soft skill requirements in the light of industry 4.0 requirements. 


\section{References:}

Adams, W. M. (2006). The Future of Sustainability: Re-Thinking Environment and Development in the Twenty-First Century. Report of the IUCN Renowned Thinkers Meeting. Gland, Switzerland: The World Conservation Union (IUCN).

Ayeisah Ramli, Roslizawati Nawawi, \&Poh, P. C. M. (2010). Employees' perceptions of employability skills needed in today's workforce among physiotherapy graduates. Procedia Social and Behavioural Sciences, $7(\mathrm{C}): 455-463$.

Ahmad et.al., 2019 (Abd Rahman Ahmad, Pannirchelvi A/P Segaran, Ng Kim Soon, Hairul Rizad Md Sapry, Siti Sarah Omar). Factors Influence The Students" Readiness on Industrial Revolution 4.o. International Journal of Recent Technology and Engineering (IJRTE) ISSN: 2277-3878, Volume-8 Issue-2S,pp: 461-466

Braha, D., \&Maimon, O. (1997). The design process: Properties, paradigms, and structure. IEEE Transactions on Systems, Man, and Cybernetics-Part A: Systems and Humans, 27: 146-166.

Bhatia, V.K \& Bremmer, S. (2012), English for business communication. Language Teaching, 45(4):410-445.

Clagett, C.A. (1997) Workforce Skills Needed by Today's Employers. Market Analysis, 5: 1-15.

Chanchaochai, D. (2012). White ocean strategy. Bangkok, Thailand:DMG Books.

Carter, F. D., Ro, K. H., \& Alcott, B. (2016). Co-Curricular Connections: The Role of Undergraduate Research Experiences in Promoting Engineering Students' Communication, Teamwork, and Leadership Skills. Research in Higher Education, 57, 363-393. https://doi.org/10.1007/s11162-015-9386-7

Deloitte Global Youth Survey (2018). Preparing tomorrow's workforce for the Fourth Industrial Revolution For business: A framework for action,PDF

Dym, C. L., Agogino, A. M., Eris, O., Frey, D. D., \& Leifer, L. J. (2005). Engineering design thinking, teaching, and learning. Journal of Engineering Education, 94:103- 120.

Doepker,M.(2019). Article on 5 ways students can graduate fully qualified for the Fourth Industrial Revolution. <https://www.weforum.org/agenda/2019/o1/how-students-can-graduate-qualified-forfourth-industrial-revolution>

Dunwill, E. (2016). 4 changes that will shape the classroom of the future: Making education fully technological. Retrieved from https://elearningindustry.com/4-changes-will-shape-classroom-of-thefuture-making-education-fully-technological

Dunne, D., \& Martin. R. (2006). Design thinking and how it will change management education: An interview and discussion. Academy of Management Learning E Education, 5: 512-523.

EzihaslindaNgah et.al. (2011). The Need for Competent work ready English Language Learners. International Conference on Education and Educational Psychology (ICEEPSY 2011)

Hiranburrana, K. (2017). Cross- cultural strategies and the use of English in international business correspondence. PASSA, 28: 72-94.

Lase, D. (2019). Education and Industrial Revolution4.0 <https://www.researchgate.net/publication/334837153 Education and Industrial Revolution 4.o>

Maarop, A. H., \& Embi, M. A. (2016). Implementation of Blended Learning in Higher Learning Institutions: A Review of Literature. International Education Studies. DOI: 10.5539/ies.v9n3P41

O'Neill, G. (2015). Curriculum Design in Higher Education: Theory to Practice. Dublin: UCD Teaching \& Learning. <http://researchrepository.ucd.ie/handle/10197/7137>

Petrillo et.al. (2018). Fourth Industrial revolution:Current practices,challenges,and opportunities,open access peer reviewed chapter. Digital Transformation in Smart Manufacturing, DOI:

10.5772/intechopen.72304. 
Passow, J. H., \& Passow, C. H. (2017). What Competencies Should Undergraduate Engineering Programs Emphasize? A Systematic Review. Engineering Education Journal, 106, 475-526.

DOI: $10.1002 /$ jee.20171

Rifkin, J. (2014). The Zero Marginal Cost Society: The Internet of Things, the Collaborative Commons, and the Eclipse of Capitalism. New York: St. Martin's Press.

Rotherham, A. J., \& Willingham, D. (2009). To work, the 21st century skills movement will require keen attention to curriculum, teacher quality, and assessment. Educational Leadership, 9:15-20.

Ranger, B.J and Mantzavinou,A.(2018). Design thinking in development engineering education: A case study on creating prosthetic and assistive technologies for the developing world, Development Engineering Vol 3, pp 166-174,https://doi.org/10.1016/j.deveng.2018.06.001

Stacho Z., Stachova K., Papula J., Papulova Z., Kohnova L. (2019). Effective Communication in Organisations Increases their Competitiveness, Polish Journal of Management Studies 19(1):391-

Sharma ,P.(2019). Digital Revolution of Education 4.o, International Journal of Engineering and Advanced Technology (IJEAT) ISSN: 2249 - 8958, Vol.9 (2),pp:3558-

Schwab, K. (2016). The fourth industrial revolution: What it means and how to respond. World Economic Forum. Retrieved from https://www.weforum.org/agenda/2016/o1/the-fourth-industrial-revolutionwhat-it-means-and-how-to-respond/

Shute, V. J. \& Becker, B. J. (2010). Innovative assessment for the 21st century. New York, NY: Springer-Verlag.

Simon, H. A. (1996). The sciences of the artificial (3rd ed.). Cambridge, MA: MIT Press.

Trilling, B., \& Fadel, C. (2009). 21 Century Skills. 21St Century Skill.

Teng etal. (2019)( Weili Teng,Chenwei Ma,Sayeed Pahlevansharif,Jason James Turner). Graduate readiness for the employment market of the 4th industrial revolution: The development of soft employability skills, Education and Training 61(236)pp.24-26 DOI: 10.1108/ET-07-2018-0154

Toffler, Alvin. (1965). "The Future as a Way of Life", Horizon magazine, Summer 1965, Vol VII, Num 3,pp 2225

Toffler, Alvin. (1970). Future Shock, https://en.wikipedia.org/wiki/Future_Shock

WEF (World Economic Forum), \& Kearney, A. T. (2018). Readiness for the Future of Production Report 2018.World Economic Forum.http://wef.ch/fopreadinessi8

Wiriyachitra, A. (2001). A thai university English scenario in the coming decade. Thai TESOL Newsletter,14(1): 4-7. 